\title{
Positive Energy Districts and Energy Efficiency in Buildings: An Innovative Technical Communication Sheet to Facilitate Policy Officers' Understanding to Enable Technologies and Procedure
}

\author{
Tiziana Ferrante and Teresa Villani * (i)
}

check for updates

Citation: Ferrante, T.; Villani, T. Positive Energy Districts and Energy Efficiency in Buildings: An Innovative Technical Communication Sheet to Facilitate Policy Officers' Understanding to Enable Technologies and Procedure. Energies 2021, 14, 8551. https://doi.org/ $10.3390 /$ en14248551

Academic Editors: Paola Clerici Maestosi and Álvaro Gutiérrez

Received: 10 November 2021 Accepted: 10 December 2021 Published: 18 December 2021

Publisher's Note: MDPI stays neutral with regard to jurisdictional claims in published maps and institutional affiliations.

Copyright: (c) 2021 by the authors. Licensee MDPI, Basel, Switzerland. This article is an open access article distributed under the terms and conditions of the Creative Commons Attribution (CC BY) license (https:// creativecommons.org/licenses/by/ $4.0 /)$.
Department of Planning, Design, and Technology of Architecture, Sapienza University of Rome, 00196 Roma, Italy; tiziana.ferrante@uniroma1.it

* Correspondence: teresa.villani@uniroma1.it

Abstract: The Horizon 2020 framework programme is defining funding strategies for research and innovation projects in European cities and promoting policies and solutions for the transition to a competitive energy system at an urban scale. Given that Horizon Europe, thanks to the Driving Urban Transition Partnership, will fund RD\&I projects regarding transitions to urban sustainability; how municipalities will implement different strategies is a relevant key to developing replicable models. We conducted this study on Italian cities through a mapping exercise on selected case studies. The aim was to provide a knowledge framework to municipalities undertaking sustainable urban development actions. We selected case studies based on energy efficiency in buildings, both in retrofits and new constructions. This highlighted how the adoption of multifaceted technological solutions blended well with each other, and led, not only, to satisfy the initial requirements, in terms of expected impacts from the single actions, but also provided relevant and replicable samples. For this, the analysis of solutions tested by different municipalities in the selected projects led to spreadsheets and indicators related to energy efficiency in buildings, which enabled a transition to a PED, which could facilitate an understanding of elements that must be clearly indicated in a preliminary design document (Directive 2014/24/UE).

Keywords: positive energy district (PED); enabling solution for PED transition; energy efficiency in buildings and real estate

\section{Introduction \\ 1.1. Smart Cities and Positive Energy Districts: A European Commission Point of View}

With the framework programme H2020, the European Commission, based on the Marseille and Toledo Declaration, council conclusions, opinions and the EU urban agenda [1-14], is defining funding strategies for cities addressing actions and programmes for sustainable urban development. Indeed, rapid population growth, deterioration of suburban areas and social inequalities, together with the increase in citizens' expectations of the quality of life and supplied services, make sustainable development policies a relevant key for energy saving and for the social participation of citizens. These topics have become the main focus in urban areas through promoting the transition to a competitive energy system based on several specific actions: reducing energy consumption and carbon footprints, supplying low-cost and low-carbon power, employing alternative fuels and mobile energy sources, employing a single and smart power network, researching new knowledge and technologies, sound decision-making, public commitment and an energy and ICT innovation market with capacity absorption $[15,16]$. Therefore, the attention on sustainable development drove, on one hand, to smart cities, and on the other, to PEDs (positive energy districts) $[17,18]$. 
Urban areas are indeed the main causes of climate change, and each action municipalities undertake for the future development of the city should contribute to characterize a positive global change. For this, municipalities play a key role in planning and decisionmaking for sustainable urban development [16].

It is clear that it was thanks to the cited documents that the European Commission developed an appropriate funding strategy to support sustainable development and sustainable urban areas. It is thanks to the contribution of a various set of stakeholders, such as the EERA Strategic Energy and Technology Plan (SET Plan) [19], JRC [20], IEA [21], JPI UE [22], the European Commission individuates, in the Horizon Europe framework programme that funding for urban sustainable development, with the Driving Urban Transition Partnership, has been directed towards positive energy districts, which represent one of the three pathways to facilitate urban transition [23].

The SET Plan, adopted by the European Union in 2008, was a first step to establish an energy technology policy for Europe; it was Europe's technology response to the challenges of meeting its targets on greenhouse gas emissions, renewable energy and energy efficiency. The integrated SET Plan identified 10 actions for research and innovation. The actions address the whole innovation chain, from research to market uptake, and tackled both financing and regulatory frameworks. Among the actions was Action 3.2, which stated, "Europe to become a global role model in integrated, innovative solutions for the planning, deployment, and replication of positive energy districts" [17]. The implementation plan, which was edited by smart cities and communities, focused on PEDs' requirements, such as an open innovation model for their planning, deployment and replication. In the TWG 3.2 implementation plan, cities were identified as the stakeholders who need to take a leading role in the integrated and holistic planning of PEDs, aligning it with their long-term urban strategies. Industries and organisations such as real estate development, construction companies, network operators, utility companies and many others, will play a vital role as solution providers.

Moreover, the Joint Programming Initiative Urban Europe-created in 2010 to address global urban challenges - thanks to the Strategic Research and Innovation Agenda 2.0 [24] and the White Paper "A Reference Framework for Positive Energy Districts and Neighbourhoods" [22], contributed to the definition of a positive energy district.

Additionally, a working group in the framework of the Joint Programming Initiative Urban Europe, analysed then collected the following in a booklet regarding PEDs [25]: PED projects in 61 urban areas, which were described according to key indicators in relation to PED projects (10 key indicators in the area of building/real estate) and to energy sustainability PED projects (5 key indicators and related sub-key indicators in the area of building/real estate). Subsequently, the above set of key indicators were extended in the ENEA research project [26] (Figure 1). 


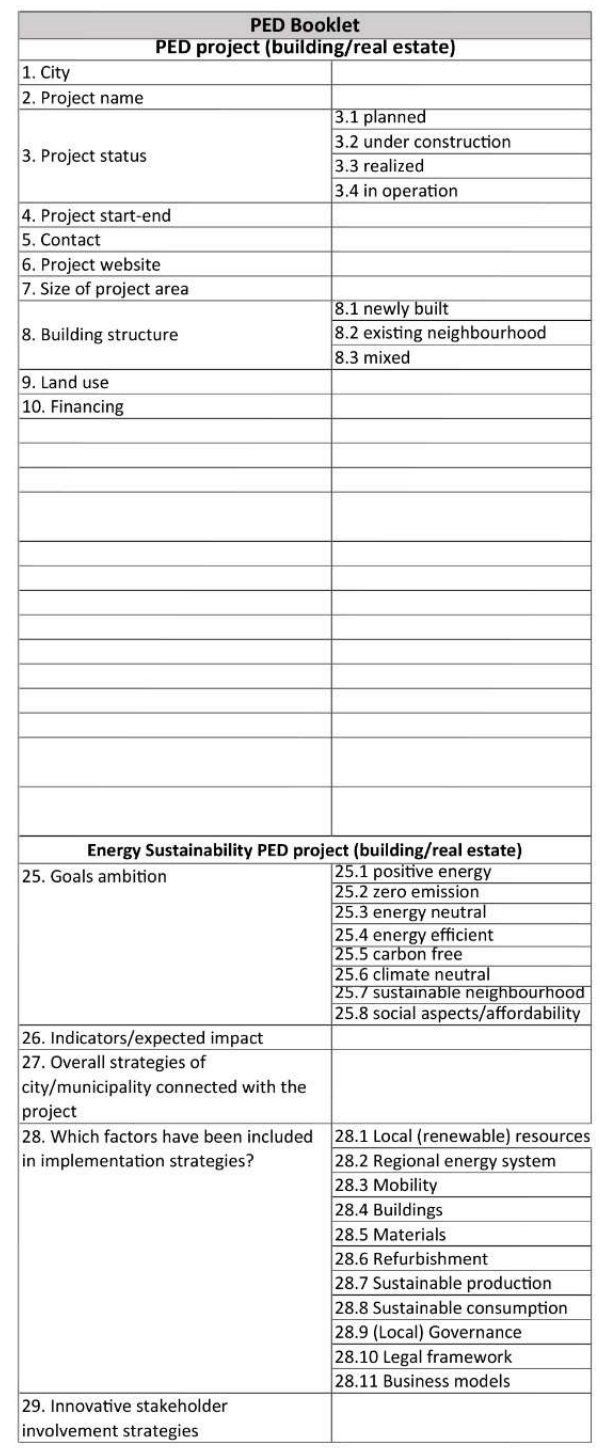

\begin{tabular}{|c|c|}
\hline \multicolumn{2}{|c|}{$\begin{array}{c}\text { ENEA Key indicators } \\
\text { PED project (building/real estate) }\end{array}$} \\
\hline 1. City & textual description \\
\hline \multirow{4}{*}{ 3. Project status } & $\begin{array}{l}\text { textual description } \\
\text { 3.1 planned }\end{array}$ \\
\hline & 3.2 under construction \\
\hline & 3.3 realized \\
\hline & 3.4 in operation \\
\hline 4. Project start-end & textual description \\
\hline 5. Contact & textual description \\
\hline 6. Project website & textual description \\
\hline 7. Size of project area & $\begin{array}{l}\text { textual description } \\
8.1 \text { newly built }\end{array}$ \\
\hline \multirow[t]{2}{*}{ 8. Building structure } & 8.2 existing neighbourhood \\
\hline & 8.3 mixed \\
\hline 9. Land use & textual description \\
\hline 10. Financing & textual description \\
\hline 11. Type of intervention & textual description \\
\hline 12. procedure for implementation & textual description \\
\hline 13. Ownership & textual description \\
\hline $\begin{array}{l}14 \text { Competition notifying body (if } \\
\text { public ownership) }\end{array}$ & textual description \\
\hline 15. Financing type & textual description \\
\hline 16. Financing amount & textual description \\
\hline 17. Implementation phases & textual description \\
\hline 18. Urban planning category & textual description \\
\hline 19. Content & textual description \\
\hline 20. Objectives & textual description \\
\hline 21. Stakeholders & textual description \\
\hline 22. Plan/Program Reference & textual description \\
\hline $\begin{array}{l}\text { 23. Involved Municipality sectors in } \\
\text { public procurement }\end{array}$ & textual description \\
\hline $\begin{array}{l}\text { 24. Procedural requirements of special } \\
\text { relevance }\end{array}$ & textual description \\
\hline
\end{tabular}

ual description

Energy Sustainability PED project (building/real estate)

\begin{tabular}{ll}
25. Goals ambition & 25.1 positive energy \\
\hline 25.2 zero emission &
\end{tabular}

25.2 zero emission
25.3 energy neutral

25.4 energy efficient

25.5 carbon free

25.6 climate neutral

26. Indicators/expected impact $\quad 25.8$ social aspects/affordability

26. Indicats/expected inpat

27. Overall strategies of
city/municipality connected with the

project

28. Which factors have been included 28.1 Local (renewable) resources

\begin{tabular}{l|l}
\hline in implementation strategies? & 28.2 Regional energy system \\
\hline
\end{tabular}

28.3 Mobility

28.4 Buildings

28.5 Materials

28.6 Refurbishment

28.7 Sustainable production

28.8 Sustainable consumption

28.9 (Local) Governance

28.10 Legal framework

29. Innovative stakeholde

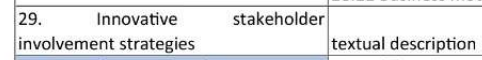

\begin{tabular}{ll}
\hline 30. Type of energy supply & textual description
\end{tabular}

\begin{tabular}{l|l|l}
\hline 31. Success factors & textual description
\end{tabular}

32. Challenges/barriers textual description

33. Enabling technologies for the

building

building's energy

35. Indicators of expected impacts

36. System solutions for energy
production

production

37. Energy flexibility solutions
38. Production and supply

extual description

extual description

extual description

textual description extual description

39. Thermal description

Energy Efficency enabling solutions (building/real estate)

40. Type of technological solutions 40.1 Thermal coat

40.2 Plug \& Play ventilated facade

40.3 Thermal break windows with

triple glazing

40.4 Solar shields

40.5 Rainwater recovery system

40.6 Thermal activation

40.7 Renewable energy

40.8 Storage

40.9 Accumulation

40.10 Control and automation

40.11 ICT system energy

Figure 1. Comparison of indicators and key indicators in the Booklet on PEDs and the ENEA research project. 


\subsection{A National Perspective on PED}

At a national level the concept of PEDs are almost unknown among municipality public officers as there are no structured national events that discuss this topic, except the ones promoted by the national Italian delegate in the JPI Urban Europe to support alignment with the European dimension. Given that this was a national research activity coordinated by ENEA [26], which analysed in depth what types of data were needed to better explain the consistency of PED projects, based on these results we elaborated the innovative technical communication sheets.

Our manuscript presents the innovative technical communication sheets (selected examples from Milan, Florence and Trento), which were elaborated for 15 Italian case studies located in the seven selected municipalities, and presents them in a booklet of PEDs, they are also analysed by Bossi et al. [27]. While both cited documents refer to the European dimension with a set of a few data types, our manuscript presents the innovative technical communication sheets, which include more detailed data concerning technological solutions (project goals, expectations in terms of energy savings, energy class, initial/final energy rating, etc., which are individuated in Figure 2) and implementation processes (entity role in different phases, activities, instruments, etc., which are individuated in Figure 3), which refer to national experiences and facilitate national public officers' understanding of positive energy districts. 


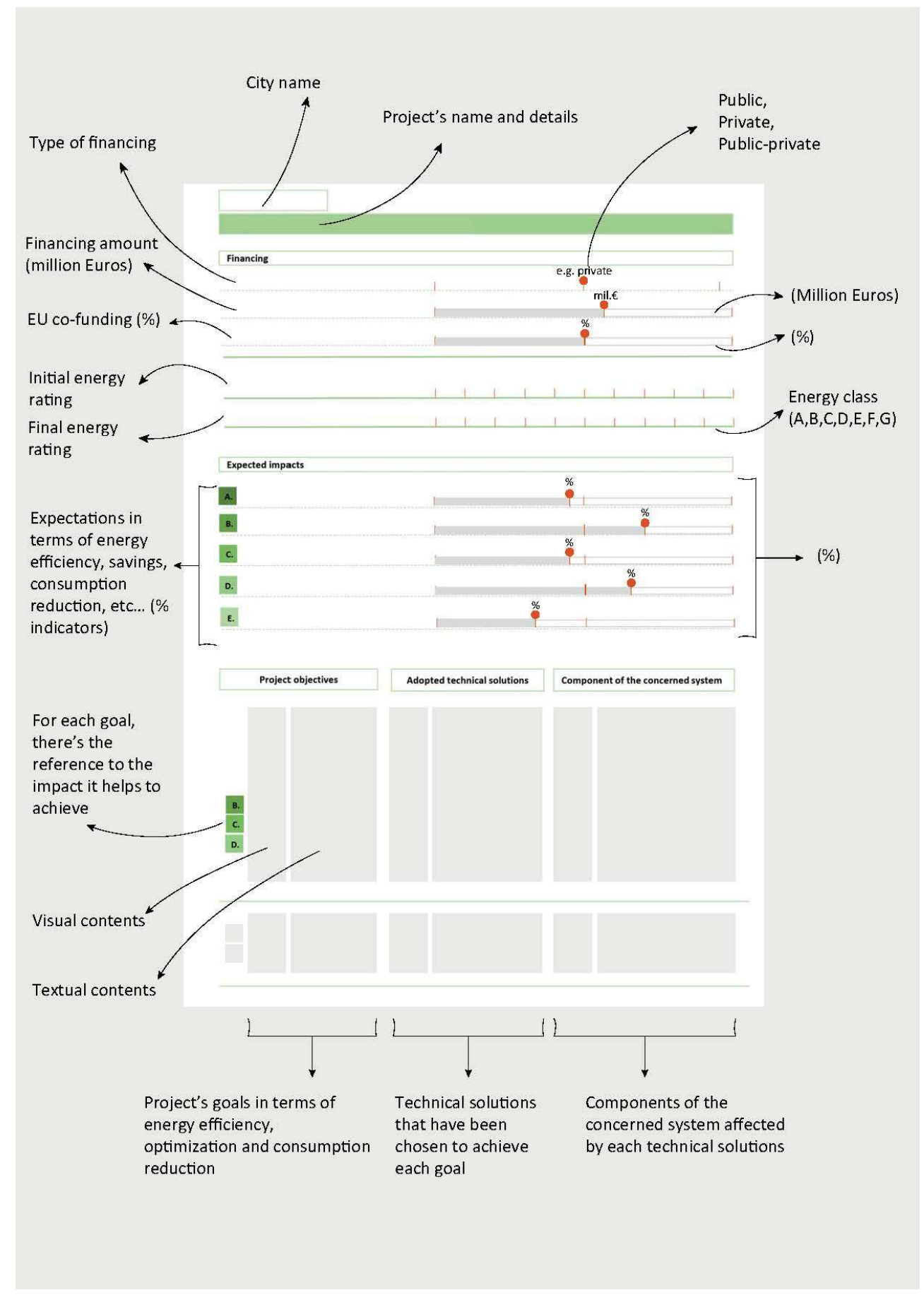

Figure 2. An example of a case-study project intervention sheet, the technological solutions. 


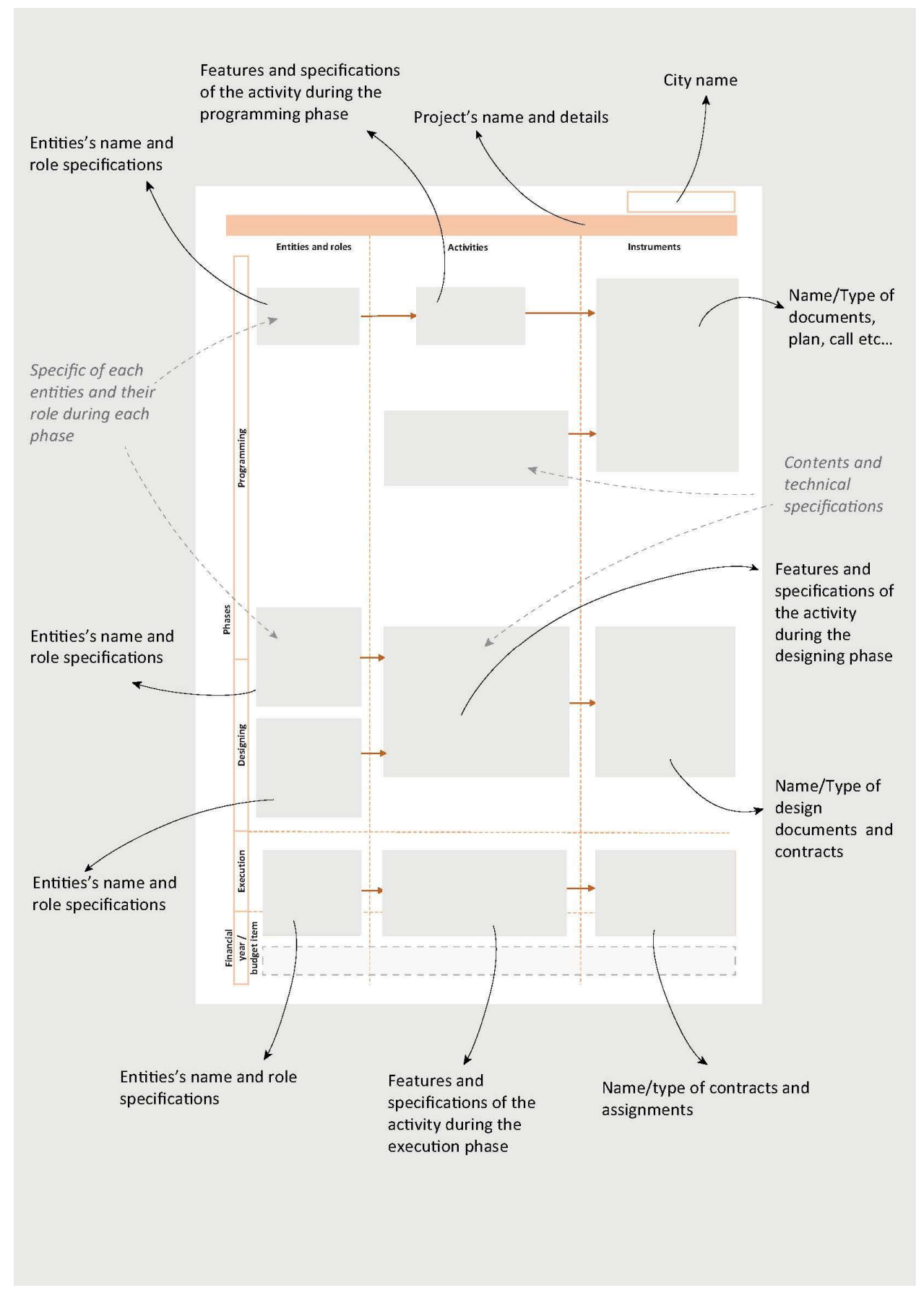

Figure 3. An example of a case-study project intervention sheet and the implementation processes.

\subsection{Positive Energy District Functions}

The guidance on PEDs includes 3 targets.

1. Efficiency: optimization of energy performance can reduce consumption in buildings and mobility infrastructures, including the existing building stock.

2. Flexibility: resilience of the regional energy system to carbon neutrality and $100 \%$ renewable energy.

3. Production: empowerment of relevant gas-emissions reductions. 


\subsection{Paper Content}

Given this, and based on results of ENEA national research [26], the researchers verified that indicators used to describe PED experiences, at least at Italian level, were not developed enough, especially those related to energy efficiency in buildings. The results of the cited research highlights that we need more key indicators as well as new areas of investigations ( 6 areas of investigations and more than 100 key indicators) to individuate the innovative and integrated solutions in the planning/implementation phases, which contribute to successfully activate the transition towards PEDs. Our research focused on the area of energy efficiency in buildings/real estate, where the cited research individuated 35 new key indicators and 11 subindicators (Figure 1 ).

The novelty of our research activity relied on the creation of an innovative technical communication sheet to facilitate policy officers' understanding of enabling technologies and procedures that improve building energy efficiency in positive-energy-district projects. The manuscript presents the innovative technical communication sheets.

\section{Materials and Methods}

\subsection{Materials}

In our research we assumed, as a starting point, the following: (1) the contents of the Booklet on PEDs was collected and edited by the PED Programme Management of JPI Urban Europe and analysed 61 urban areas, 7 of them in Italy, namely Parma, Roma, Milano, Bolzano, Firenze, Lecce and Trento, proposing a characterization through a set of given elements; (2) results in the ENEA research implemented the original set in the Booklet on PEDs according to a more comprehensive approach, which considered each building as the result of a process characterized by phases, requirements and performance [28].

The starting point was to aggregate data that referred to a specific building, in order to obtain authorization to build, in a single technical communication sheet, then to implement the sheet with those characteristics to enable the building itself to be a physical node that enabled a positive energy district.

Our activity focused on the elaboration of an innovative technical communication sheet, which described, in an effective and easy way, key indicators related to buildings.

\subsection{Methods}

Research objectives: The research objectives aimed to individuate how to communicate the key indicators related to energy efficiency in PED building projects to policy officers in a municipality. These were based on the list of key indicators in the ENEA project, which were used to perform a deeper analysis on the selected case studies (Figure 1).

Research methodology: The research methodology was based on a theoretical perspective that highlighted technology-enabling factors for energy efficiency in buildings as nodes in a positive energy district, as well as rules, regulations and public procurement procedures for rehabilitation, recovery or new buildings.

The methodology was based on three phases.

1. Collection of objectives, aims and strategies in the PED building projects assumed as case studies;

2. Analysis of case studies according to the new key indicators related to energy efficiency in buildings/real estate;

3. Creation of technical communication sheets for easier understanding.

The paper presents the results of the research activities. This work focussed on identifying a technical communication sheet to facilitate the comprehension of key indicators that concern energy efficiency in buildings/real estate and the public procurement procedure. This work also aimed to facilitate the comprehension and understanding by civil servants in municipalities, which aimed to activate the transition to positive energy districts.

According to each case study, and to the above-mentioned key indicators, it was necessary to present analysis results on energy-efficiency solutions in buildings as well 
as on public procurement procedures in each case study. This helped facilitate the comparison and identification of enabling factors for the transition to a PED, as related to the specific topic.

Thus, two types of technical communication sheets were created.

To define the spreadsheet structure, the study considered the data collected in the 7 Italian municipalities, which were already selected as "in transition to a PED" in the Booklet on PEDs [25], and 15 energy-efficiency interventions on buildings (7 already indicated in the Booklet of PEDs and 8 new ones), which were identified as case studies specifically referring to energy efficiency in buildings/real estate projects.

Then according to the type of indicators, we developed one technical communication sheet describing energy-efficiency solutions in building/real estate case studies and a second one describing the public procurement process.

The contents of the technical communication sheet describing energy-efficiency solutions in the buildings and real estate case studies included the following:

- General information such as the city's name and the project's name and details;

- Quantitative and qualitative data, such as type of financing, financing amount, EU co-funding (\% indicators);

- Data on energy class upgrades, such as initial energy rating and final energy rating (energy class from A to G);

- Information on expected impacts, such as expectations in terms of energy efficiency, savings, consumption reduction, etc. (\% indicators);

- Data on adopted technology solutions in response to project objectives (project goals in terms of energy efficiency, optimization and consumption reduction and their impact when achieved) (Figure 2).

The contents of the technical communication sheet describing the public procurement process included the following:

- General information such as the city's name and the project's name and details;

- Building phases (programming, designing, execution);

- Financial information.

For each phase we identified entities and roles (which were specific for each entity and role during each phase), activities (in terms of procedures, rules, requirements, financing, etc., contents and technical specifications, instruments (the name/type of documents, plans, calls, etc., and the name/type of design documents), contracts and assignments) (Figure 3).

The proposed technical communication sheet was undoubtedly an effective way to present results and to compare building solutions and public procurement procedures.

The frames were designed with the aim of facilitating the use of the content information by the principles of information visualization. This improved the cognitive process for an understanding of the spreadsheet's content through a balanced use of visual and textual codes, which were also used to achieve a different type of communication effectiveness, depending on the nature of the information (qualitative and quantitative) and on the recipients.

Specifically, for frames of the implementation process of operations, a lot of the collected data in the spreadsheets concerned descriptive topics. These needed a textual language for communication, but, at the same time, must communicate an organized sequence of phases concerning operators and proper tools for their specific activities.

In this case, to represent the complexity of the building process and the public procurement (with its relevant dataset) of the analysed case studies, we chose a representation that integrated text-based information organized within flow diagrams that facilitated a logical sequence with links among areas.

The aim of the proposed graphic organisation was to disseminate this information to municipal officials/civil servants (competent departments and offices) who wanted to start an urban development plan for driving ecological transitions and PEDs. By learning from this information, which also displayed a more immediate visual representation, officials 
could take out useful instruments for the selection of policy and decision making on funding strategies, appropriate procurement processes and key documents to ensure the quality of the operations, in terms of energy efficiency and sustainability, and to identify any issues (diagram bugs) and anticipate solutions.

In this way the exploratory analysis of the data benefitted from the visual representation through fast information communication that otherwise hid within the spreadsheets. This positively affected the target in replicating the case studies' procedures. Visual attributes, such as colour, size, proximity and visual representation of quantitative data, as well as textual content, were used for the frames on technological solutions, to convey complex data that would otherwise require huge cognitive processing. We collected the set of data through the desk activity on innovative solutions for the energy efficiency of the case studies and on expected impacts. We then reorganized them into a consistent form that was able to communicate the target context, taking well into account the key recipients as municipal technical office chiefs, architects, etc.

\section{Results}

The method for the frame implementation was to report a first phase of all information taken from a critical reading of the analysed projects and to gradually remove redundant information, or information liable to further technical insight. This way allowed us to bring out only first-level data, which were useful to identify, with an immediate representation, the impact of the positive solution within the PEDs. (Figure 4). In addition, this helped technicians consider the content's consistence for their replicability.

We carried out work on the spreadsheet affordance, i.e., those real or perceived properties which were self explanatory, thus simply showing them to informed recipients supported its multiple uses in terms of data interaction.

The use of visual representation for quantitative context data made it easier to use the preconditions for starting energy-efficiency operations based on the need for funding. In particular it showed the impacts of EU grants.

The different levels of colour saturation and intensity facilitated the process of visual recognition for most relevant data.

The choice of the use of icons made effective mental representations, facilitated fast communication and, in any case, kept a close link between visual and textual terminology.

This information, together with the experience of recipients, should be able to produce knowledge on the project objectives, on the specificities of adopted solutions and on the key components of the building system for energy efficiency. Knowledge was therefore the main objective of the communication process. This empowered technicians to express a meaningful consideration on data and to develop the technical knowledge for the replication of the solutions.

In order to assess the on-field effectiveness of the frames we were holding, we had many online meetings with specific stakeholders of the involved municipalities, from which we received useful feedback on how to improve the communicativeness of the frames; by implementing content and graphics, for example.

Indeed, these frames were also prototypes on which to test the accessibility of information content and its actual use by checking compliance with replicable solutions. The obtained feedback, and the application of information visualization principles, were also crucial for the ongoing design of the digital database.

Moreover, the communication outline of the frames was particularly effective for a comparative assessment between the procedures of the operations in more cities and the technological solutions for energy-efficiency operations in the case studies.

Indeed, the objective comparison between homogeneous datasets was visually facilitated by reducing the error during data comparison, which were carried out on spreadsheets. 

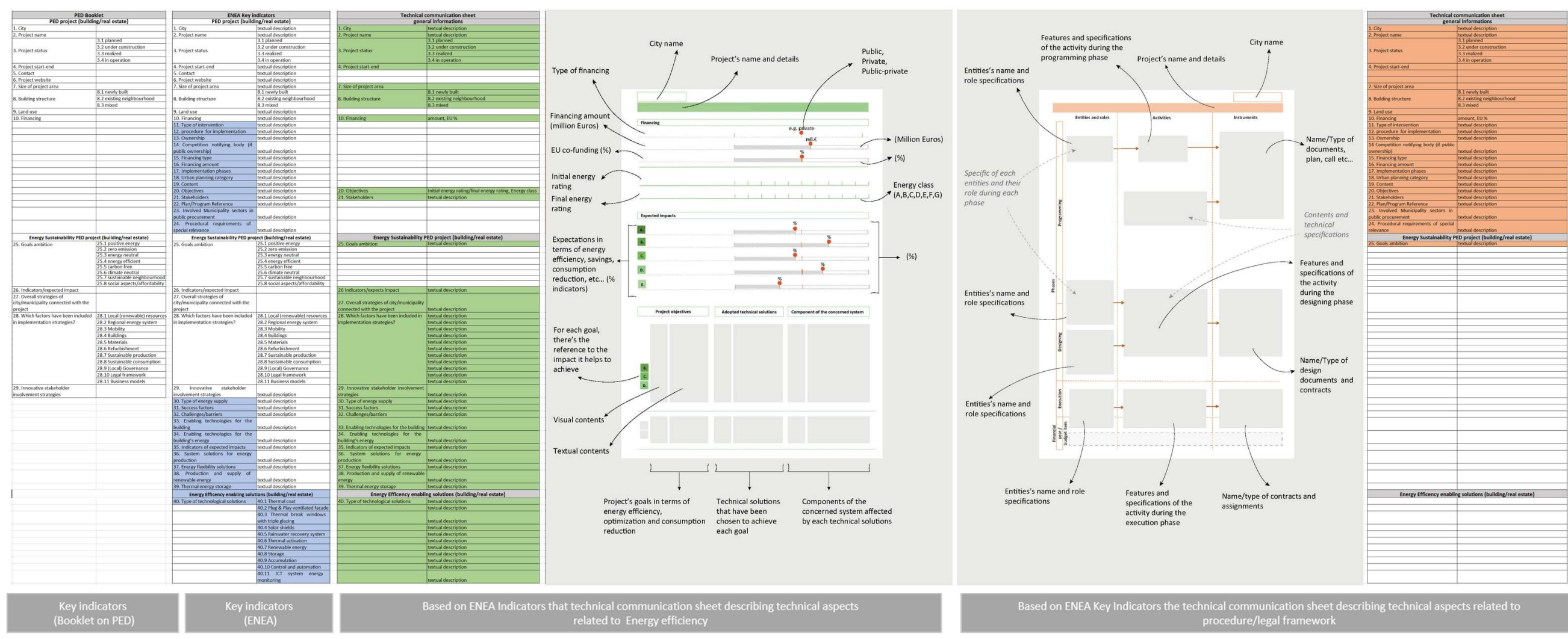

Based on ENEA Key Indicators the technical communication sheet de
procedure/legal framework

Figure 4. Comparison of a technical data sheet and a technical communication sheet. 
For the frame of technological solutions, the selected communication outline could highlight the "weight" of the results achieved by the different solutions, compared within each indicator, related to the expected impacts. Such impacts needed a close link, not only to adopt solutions, but also for the building system components that were involved in the surveyed energy-efficiency operations (Figure 5).

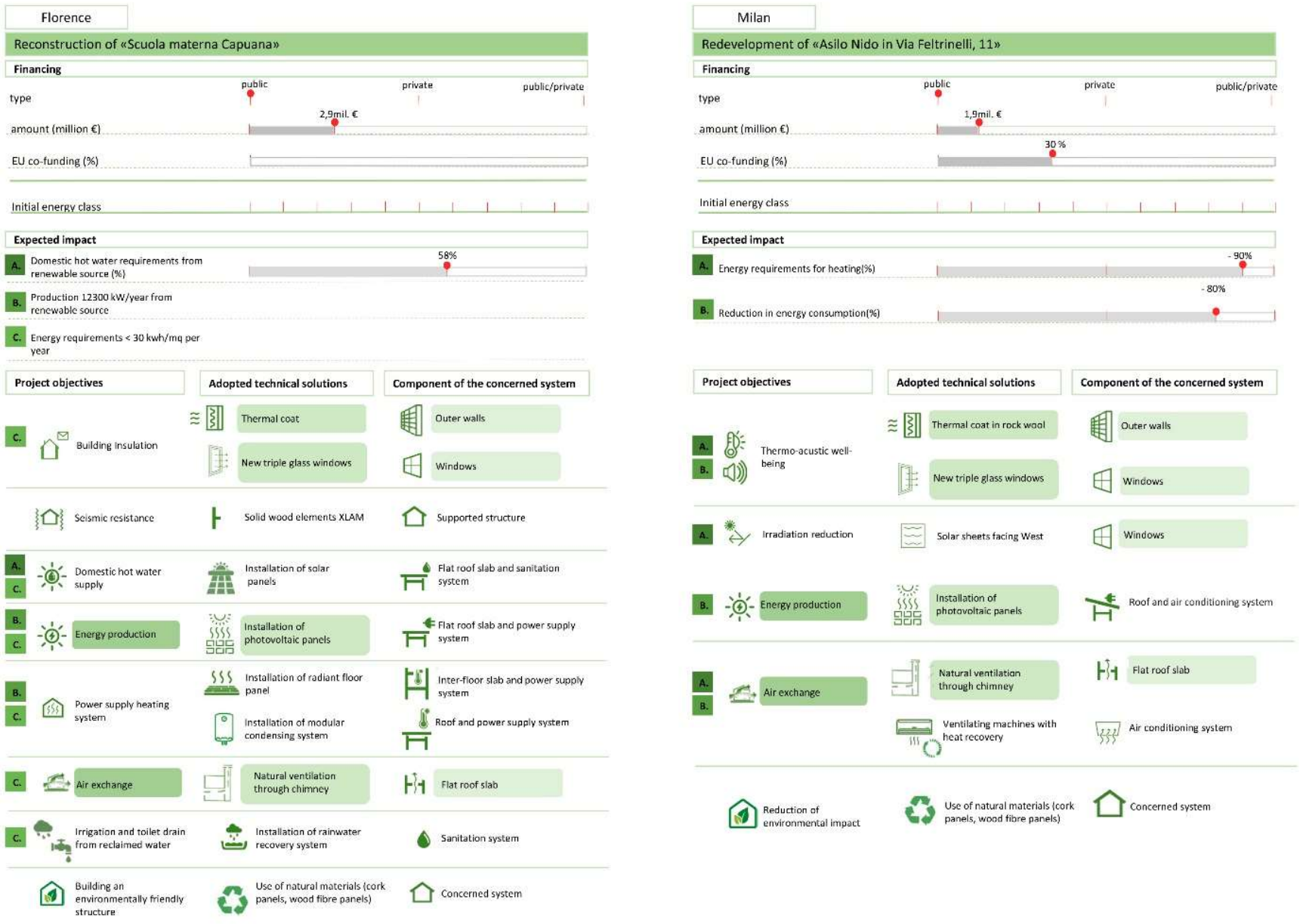

Figure 5. Milan and Florence case study: comparative analysis of technological solutions.

For the frame of the execution process through to the comparison of flow diagrams, we could focus on the critical phases of the building process and on the potential for different instruments the municipalities chose for each activity, as well as the extensive impact on the quality and achievement of the PED target (Figure 6). 

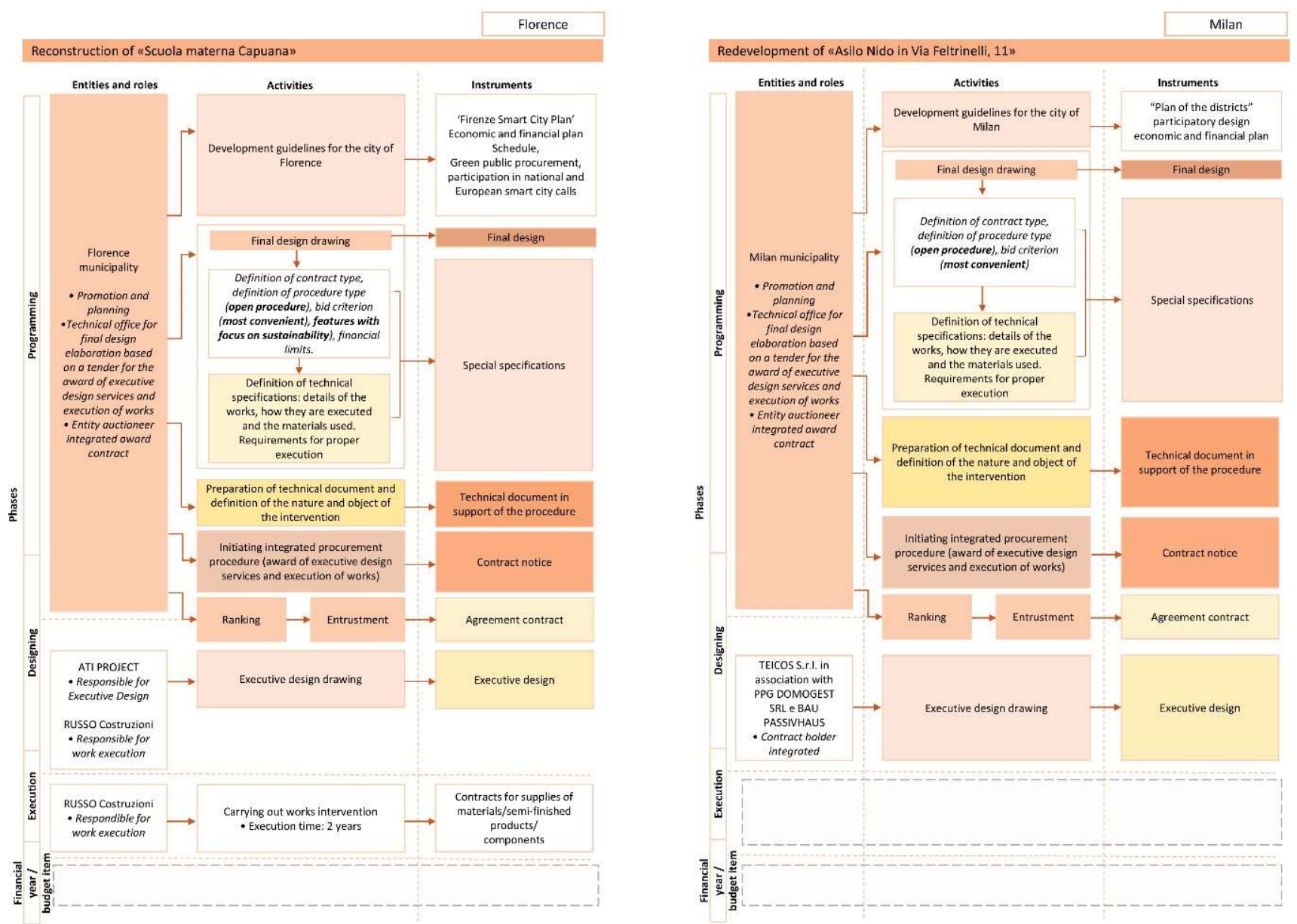

Figure 6. Milan and Florence case study: comparative analysis of the implementation processes.

\subsection{Technical Communication Sheets on Technological Solution}

Systematization of the information collected in the spreadsheets allowed a univocal interpretation of the different analysed projects, in terms of the innovative technological solutions and the processes that empowered planning, development, implementation and management of different actions. The importance of the analysis of technological solutions concerned the topic of energy efficiency: the design of such actions was the result of strategic policies and the use of specific solutions to achieve established objectives. Such solutions took place to achieve a sustainable architecture based on a low environmental impact of the building through resource saving and pollution reduction in all lifecycle phases. There was also a positive approach to "on-site" energy production using specific systems that used renewable sources. Within the study carried out in this first phase, we found that projects stood out for the adoption of different solutions that were able to improve energy performance; for this, we identified an in-depth study on how adopted technological choices interacted with the whole building system. We reported the sheet sample of the case study of the city of Trento (Figure 7). 


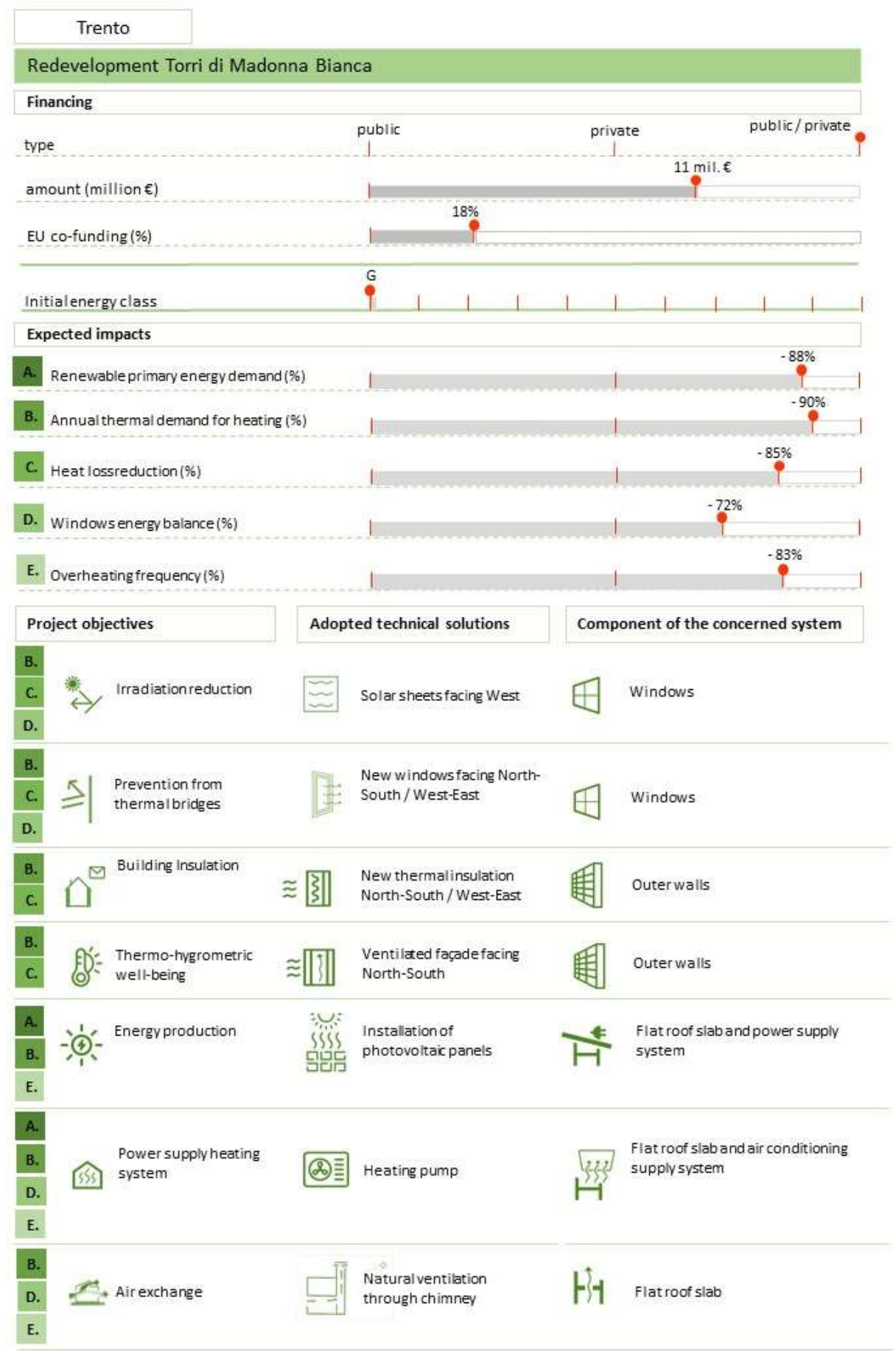

Figure 7. Trento case study project intervention: the technological solutions.

We conducted the project's survey and linked it closely with the analysis of each building process.

\subsection{Technical Communication Sheets on Implementation Processes}

In this section we discuss the spreadsheet on implementation processes concerning building rehabilitation. In reference to the procedures we outlined, with the involvement of municipalities and stakeholders, we identified specific actions that cities developed. The project variety depended on factors including the programming methods of actions, the financing policies and the stakeholders' involvement through participatory processes. 
We reported an example of the described sheet in the case study of the city of Trento (Figure 8).

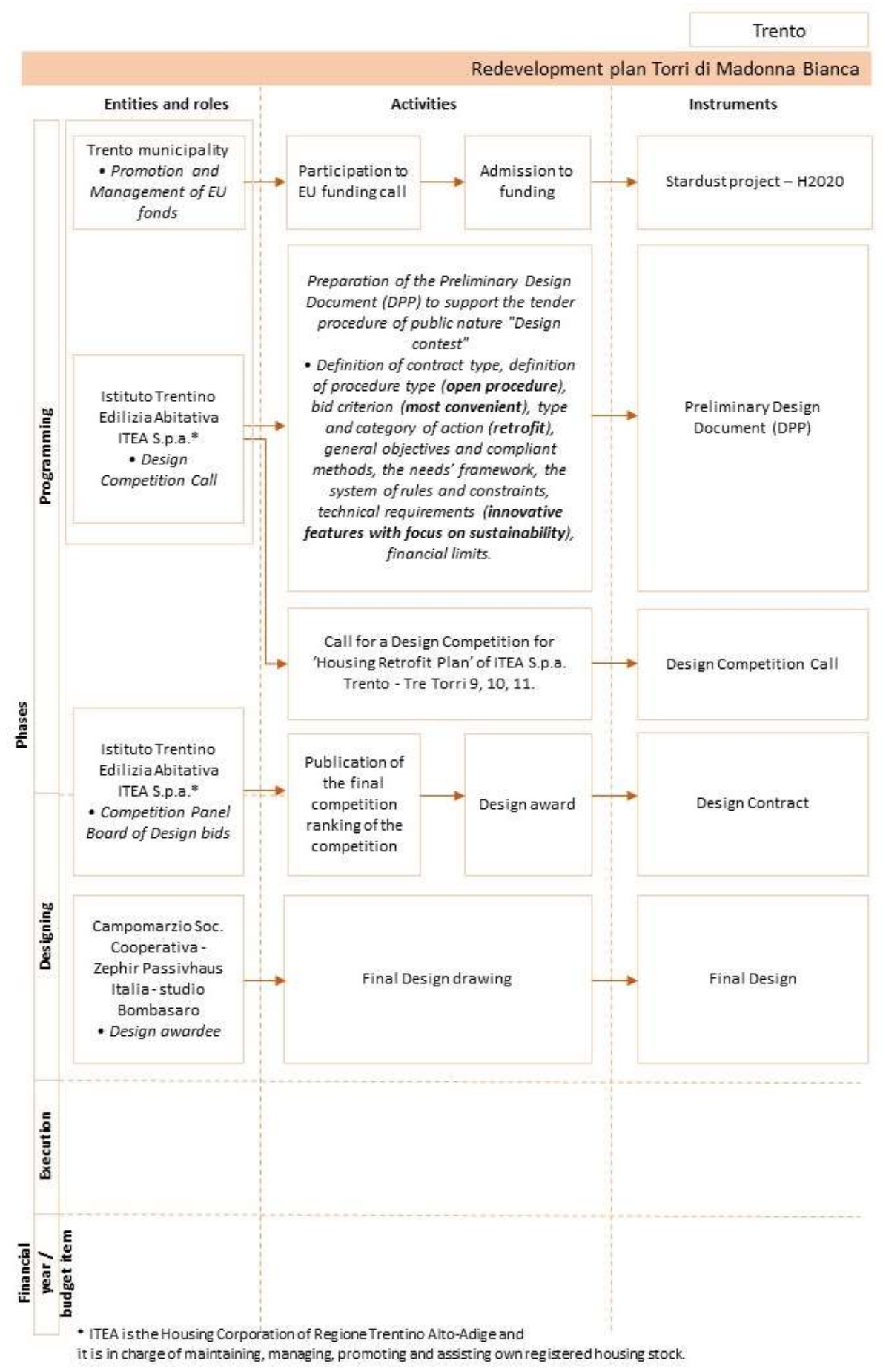

Figure 8. Trento case study project intervention: the implementation processes.

3.3. New Set of Indicators Comparing the Requirement in the Preliminary Design Document with the Technological Solutions Adopted

The result obtained for each project, from these two sheets, was not only useful for specific content but especially for the link we could detect between the two observation areas. Taking Trento, again, as an example case study, the analysis of the implementation processes led us to highlight the relevance of the documents used since the programming phase. Indeed, the quality of the pre-design document, which we found complete and 
clear in the compliance to specific requirements of energy sustainability, highlights several indicators, which proved to be valuable during the preparatory phase prior to design (Figure 9); these indicators did not limit the building scale, but detected all factors of the action.

\begin{tabular}{|c|c|c|}
\hline \multicolumn{3}{|c|}{ Technological solutions - Trento - Torri di Madonna Bianca } \\
\hline Requirement & Objective & Adopted technological solutions \\
\hline $\begin{array}{l}\text { Integration with } \\
\text { landscape/environment } \\
\text { surroundings }\end{array}$ & & $\begin{array}{l}\text { Gres panels preserving materic and } \\
\text { colour features of the original towers }\end{array}$ \\
\hline $\begin{array}{l}\text { Shorter construction site } \\
\text { duration }\end{array}$ & & $\begin{array}{l}\text { Use of dry and precast assembly } \\
\text { systems }\end{array}$ \\
\hline Compliance to housing needs & \begin{tabular}{|l|l|}
$\begin{array}{l}\text { Residents staying home during } \\
\text { operations onsite }\end{array}$ & \\
\end{tabular} & \\
\hline \multirow[t]{2}{*}{$\begin{array}{l}\text { Thermal insulation of matt } \\
\text { surfaces }\end{array}$} & Prevention from thermal bridges & Thermal loss reduction \\
\hline & $\begin{array}{l}\text { Energy efficiency (energy class } \\
\text { upgrade) }\end{array}$ & $\begin{array}{l}\text { Continuous insulating jacket of building } \\
\text { shell-Optimized passive solar supply }\end{array}$ \\
\hline \multirow{2}{*}{ Execution flexibility } & Fast execution phases & $\begin{array}{l}\text { Plug\&Play ventilated facade system } \\
\text { installed out of the floors }\end{array}$ \\
\hline & $\begin{array}{|ll|}\begin{array}{l}\text { Integrability of elevation } \\
\text { components }\end{array} & \\
\end{array}$ & $\begin{array}{l}\text { New panels shall be with the same size } \\
\text { of the current ones }\end{array}$ \\
\hline Fire safety & Use of non-combustible materials & $\begin{array}{l}\text { Specific materials (mineral wool, gres, } \\
\text { metal, glass) }\end{array}$ \\
\hline New transparent partitions & New windows & New steel windows \\
\hline Usability/accessibility & \begin{tabular}{|l|l|}
$\begin{array}{l}\text { Easy opening/closing of } \\
\text { doors/windows }\end{array}$ & \\
\end{tabular} & $\begin{array}{l}\text { Natural ventilation system through } \\
\text { automatized opening }\end{array}$ \\
\hline Shielding systems installation & Proper natural lighting & $\begin{array}{l}\text { Independent solar sheets for ensuring } \\
\text { full protection from solar irradiation }\end{array}$ \\
\hline System integration & Preserving original features & Additional storey for the new system \\
\hline \multirow[b]{2}{*}{ New air-conditioning systems } & \multirow[b]{2}{*}{ Energy efficiency upgrade } & Photovoltaic system from 70kWpeak \\
\hline & & Heating pump \\
\hline Preserving original features & $\begin{array}{l}\text { Check of outwards facing and } \\
\text { surroundings }\end{array}$ & $\begin{array}{l}\text { Terrace with panoramic view on the } \\
\text { valley }\end{array}$ \\
\hline $\begin{array}{l}\text { Regulated architectural } \\
\text { composition flexibility }\end{array}$ & Limited works on some features & \\
\hline \multicolumn{3}{|l|}{$\begin{array}{l}\text { Flexibility of adopted technical } \\
\text { solutions }\end{array}$} \\
\hline Improving thermal comfort & $\begin{array}{l}\text { Reduction of thermal bridges of } \\
\text { balconies }\end{array}$ & $\begin{array}{l}\text { Use of high-performance insulating } \\
\text { materials }\end{array}$ \\
\hline Complying with size rules & Adding cubature & $\begin{array}{l}\text { "A" Energy class upgrade allows a } \\
\text { cubature bonus of } 350 \mathrm{mc} \text { for each } \\
\text { housing block }\end{array}$ \\
\hline \multirow[t]{2}{*}{ Privacy and safety } & \begin{tabular}{|l}
$\begin{array}{l}\text { Safety of outer partition } \\
\text { components }\end{array}$ \\
\end{tabular} & Use of proper railings \\
\hline & Ensuring privacy among balconies & Use of partitions \\
\hline $\begin{array}{l}\text { Enhanced accessibility and } \\
\text { usability }\end{array}$ & $\begin{array}{l}\text { Architectural barriers overcome - } \\
\text { recognizability of main entrances }\end{array}$ & $\begin{array}{l}\text { Use of high quality materials for } \\
\text { accessible entrance }\end{array}$ \\
\hline $\begin{array}{l}\text { Easy maintenability of green } \\
\text { areas }\end{array}$ & $\begin{array}{l}\text { Maintaining through time common } \\
\text { and private green areas }\end{array}$ & \\
\hline $\begin{array}{l}\text { Highest re-use of building waste } \\
\text { (CAM) }\end{array}$ & & Check of use of building materials \\
\hline $\begin{array}{l}\text { Cost-effectiveness during and } \\
\text { after construction }\end{array}$ & & $\begin{array}{l}\text { Cost-effectiveness for using a standard } \\
\text { (photovoltaic) system }\end{array}$ \\
\hline
\end{tabular}

Figure 9. Indicators described in the preliminary design document for the Trento case study.

The design phase, which followed the public procurement procedure, was tendered for by the design contract, in accordance with the DPP requirements. This produced an easier selection criteria procedure for the bid and for the selection of especially energy-efficient technological solutions. Strategic policies were also a driver to meet the requirements as 
reported among expected impacts in terms of energy. Thus, the overall process quality that included sustainability topics from the early stages of promotion and programming to all implementation tools, should clearly result in success of the action with a sensible design of the technological solutions in compliance with the PED criteria.

\section{Discussion}

Although our research activity will support further in-depth investigation, the proposed frame that describes PED projects, appears promising for the organization of information and has a clear focus on strategies and solutions, which will facilitate public officers in understanding the main characteristics of PED projects.

Several discussions are ongoing among most prominent European networks (EERA JPSC PED modules, SET Plan Action 3.2 PED Programme/DUT PED pillar, COST Action PED-EU-NET, IEA EBC Annex 83, UERA PED WG, PED-related SCC01 projects, H2020 SCC01 TG Replication, SCALE, Smart Cities Marketplace) to define a common and shared definition of a PED, as well as to individuate key indicators that capture the true PED essence.

No matter what the key indicators will be, our research activity highlighted the importance of effective communication.

With increasing numbers of city authorities embracing the PED concept, and an increasing number of PED-related projects, there is a lack in communication characteristics, results, aims and goals in PED projects, in knowing that clear and effective communication facilitates comparison, evaluation and replication.

Our research activity was aligned with these contents and our aim was to fulfil the existing gap by contributing, with our results, methods of organizing information to facilitate understanding of PED projects.

\section{Conclusions}

Although our research will further develop an in-depth analysis of other aspects of cities from our case studies (e.g., identification and qualification of urban ecosystem stakeholders and sectors of competence with their involvements at national, regional, provincial and local levels), the results presented in this paper seem interesting and in line with ongoing European debate.

There is a need for effective communication on PED case studies that highlight information related to strategies and solutions implemented by the municipalities to facilitate the transition to PEDs, in the specific field of energy efficiency in the building/real estate sectors.

Effective communication on findings related to PED pathways will encourage and facilitate synergies among urban ecosystem stakeholders by activating virtuous communication processes and improving the understanding of actions to support PED transition.

Indeed, the new set of indicators identified by the ENEA optimizes the understanding of the technicalities of PED projects, thanks to a national research project we carried out to identify an effective way to communicate results and findings in an appropriate way to public officers.

Among technicalities, the most prominent was within the building process (planning of sustainable actions, design development, implementation and management), which represented the fundamental activity public officers take to move from ideas to reality.

That is why our main aim was to communicate the effectiveness of solutions and procedures that could be assumed as a set of replicable good practices among public officers involved in technical offices or sectors within municipalities: from several tender, technical and administrative documents, as well as financing budgets required for activating public tenders.

Finally, a particular attention was paid to the planning phase of the building process and to the contents of the preliminary design document where public officers within municipalities expressed requirements and addressed the choices in a meaningful way. 
Indeed, a clear and effective qualification of the demand arose from the necessary conditions for the implementation of technological and financial solutions. In fact, the key role of public officers of municipalities was clear from the coherence and specificity of the technical planning documents.

Without their involvement and support there was no chance in the area of positive energy districts, due to the complexity of the involved areas of expertise in road mapping urban transition strategies.

Author Contributions: Conceptualization, T.F. and T.V.; methodology, T.F.; validation, T.F. and T.V.; formal analysis, T.V.; investigation, T.F. and T.V.; resources, T.F. and T.V.; data curation, T.V.; writingoriginal draft preparation, T.F. and T.V.; supervision, T.F.; project administration, T.F. All authors have read and agreed to the published version of the manuscript.

Funding: Project funded by Ricerca di Sistema, Report RdS/PTR (2020)/040.

Institutional Review Board Statement: Not applicable.

Informed Consent Statement: Not applicable.

Data Availability Statement: The data presented in this study are available on request from the corresponding author.

Acknowledgments: We would like to thank the public officials of the municipalities included in the Booklet on PEDs and the Architect Eleonora Di Manno, who participated in data collection, analysis and report.

Conflicts of Interest: The authors declare no conflict of interest.

\section{References}

1. 'Marseille Declaration' Adopted at the Informal Ministerial Meeting of Ministers Responsible for Urban Development on 25 November 2008. Available online: http://www.eib.org/attachments/jessica_marseille_statement_en.pdf (accessed on 9 December 2021).

2. Toledo Declaration, Adopted at the Informal Ministerial Meeting of Ministers on Urban Development of 22 June Adopted 2010 in Toledo. Available online: http:/ /www.ccre.org/docs/2010_06_04_toledo_declaration_final.pdf (accessed on 9 December 2021).

3. Territorial Agenda of the EU 2020, Agreed at the Informal Ministerial Meeting of Ministers responsible for Spatial Planning and Territorial Development of 19 May 2011 in Gödöllő. Available online: http:/ / ec.europa.eu/regional_policy/en/information/ publications/communications/2011/territorial-agenda-of-the-european-union-2020 (accessed on 9 December 2021).

4. Urban Agenda for the EU-'Pact of Amsterdam', Agreed at the Informal Meeting of EU Ministers Responsible for Urban Matters on 30 May 2016 in Amsterdam. Available online: http:/ /ec.europa.eu/regional_policy/sources/policy/themes/urbandevelopment/agenda/pact-of-amsterdam.pdf (accessed on 9 December 2021).

5. The General Affair Council of the European Union-Council Conclusions on the Urban Agenda for the EU, 24 June 2016, the Council of the European Union. Available online: http://www.consilium.europa.eu/en/press/press-releases/2016/06/24 / conclusions-eu-urban-agenda/ (accessed on 9 December 2021).

6. Council Conclusions on the Objectives and Priorities of the EU and Its Member States, Adopted for the Third United Nations Conference on Housing and Sustainable Urban Development (Habitat III), 2016. Available online: http:/ /www.consilium.europa. $\mathrm{eu} / \mathrm{en} / \mathrm{press}$ /press-releases/2016/05/12/conclusions-on-habitat-iii/ (accessed on 9 December 2021).

7. Report from the Commission to the Council on the Urban Agenda for the EU, COM (2017) 657 final. 2017. Available online: https:/ / ec.europa.eu/regional_policy/sources/policy/themes/urban/report_urban_agenda2017_en.pdf (accessed on 9 December 2021).

8. Opinion of the Committee of the Regions 'Towards an Integrated Urban Agenda for the EU', Adopted on 25 and 26 June 2014. Available online: http:/ / eur-lex.europa.eu/legal-content/EN/TXT/PDF/?uri=CELEX:52013IR6902\&from=PL (accessed on 9 December 2021).

9. Opinion of the Committee of the Regions 'Concrete Steps for Implementing the EU Urban Agenda', Adopted on 7 April 2016. Available online: http:/ / eur-lex.europa.eu/legal-content/EN/TXT/?uri=CELEX\%3A52015IR5511 (accessed on 9 December 2021).

10. Committee of the Regions-Commission for Territorial Cohesion Policy and the EU Budget 'The Follow-Up Strategy on the Implementation of the Urban Agenda for the EU'. 2016. Available online: http://memportal.cor.europa.eu/Handlers/ViewDoc. ashx?doc=COR-2016-04284-00-01-TCD-TRA-EN.docx (accessed on 9 December 2021). 
11. European Economic and Social Committee Opinion: The 2030 Agenda-A European Union Committed to Sustainable Development Globally, Adopted on 20 October 2016. Available online: http:/ / www.eesc.europa.eu/en/our-work/opinionsinformation-reports / opinions / 2030-agenda-european-union-committed-support-sustainable-development-goals-globallyown-initiative-opinion (accessed on 9 December 2021).

12. Resolution of the European Parliament of 3 July 2018 on the Role of Cities in the Institutional Framework of the Union (2017/2037(INI)). Available online: http:/ / eur-lex.europa.eu/legal-content/EN/TXT/PDF / ?uri=CELEX:52018IP0273\&rid=2 (accessed on 9 December 2021).

13. Report of the Parliamentary Committee on Regional Development on the Urban Dimension of EU policies (2014/2213(INI)), Adopted on 17 June 2015. Available online: https://www.europarl.europa.eu/doceo/document/A-8-2015-0218_EN.html (accessed on 9 December 2021).

14. Opinion of the European Committee of the Regions-'Implementation Assessment of the Urban Agenda for the EU', Adopted on 5 July 2018. Available online: http:/ / memportal.cor.europa.eu/Handlers/ViewDoc.ashx?pdf=true\&doc=COR-2017-06120-00-00 -AC-TRA-EN.docx (accessed on 9 December 2021).

15. Østergaard, P.A.; Maestosi, P.C. Tools, technologies and systems integration for the Smart and Sustainable Cities to come. Int. J. Sustain. Energy Plan. Manag. 2019, 24, 1-6. [CrossRef]

16. European Union. Regional Policy. City of Tomorrow. Challenges, Visions, Ways Forward. 2011. Available online: https: / / ec.europa.eu/regional_policy/sources/docgener/studies/pdf/citiesoftomorrow/citiesoftomorrow_final.pdf (accessed on 2 November 2021).

17. SET-Plan Action 3.2 on Smart Cities and Communities. Available online: https://jpi-urbaneurope.eu/wp-content/uploads/2018 /09/setplan_smartcities_implementationplan.pdf (accessed on 2 November 2021).

18. Joss, S.; de Jong, M.; Schraven, D.; Zhan, P. Sustainable-Smart-Resilient-Low Carbon-Eco-Knowledge cities; making sense of a multitude of concepts promoting sustainable urbanization. J. Clean. Prod. 2015, 109, 25-38. [CrossRef]

19. The EU SET-Plan. EERA. Available online: https://www.eera-set.eu/eera-in-the-eu/set-plan.html (accessed on 2 November 2021).

20. Shnapp, S.; Paci, D.; Bertoldi, P. Enabling Positive Energy Districts Across Europe: Energy Efficiency Couples Renewable Energy, EUR 30325 EN; Publications Office of the European Union: Luxembourg, 2020. [CrossRef]

21. IEA EBC-Annex 81-Data-Driven Smart Buildings. Available online: https:/ /annex81.iea-ebc.org/ (accessed on 2 November 2021).

22. Hinterberger, R.; Gollner, C.; Noll, M.; Meyer, S.; Schwarz, H.-G. White Paper on PED Reference Framework for Positive Energy Districts and Neighbourhoods, JPI Urban Europe and SET-Plan 3.2 Programme on Positive Energy Districts. 2020. Available online: https:/ /jpi-urbaneurope.eu/wp-content/uploads/2020/04/White-Paper-PED-Framework-Definition-2020323-final.pdf (accessed on 2 November 2021).

23. Proposal for the European Partnership Driving Urban Transitions. 2020. Available online: https://ec.europa.eu/info/sites/ default/files/research_and_innovation/funding/documents/ec_rtd_he-partnerships-driving-urban-transitions.pdf (accessed on 2 November 2021).

24. Joint Programming Initiative Urban Europe. Strategic Research and Innovation Agenda 2.0. 2019. Available online: https: //jpi-urbaneurope.eu/wp-content/uploads/2019/02/SRIA2.0.pdf (accessed on 2 November 2021).

25. Joint Programming Initiative Urban Europe. Europe Towards Positive Energy Districts. 2020. Available online: https://jpiurbaneurope.eu/wp-content/uploads/2020/06/PED-Booklet-Update-Feb-2020_2.pdf (accessed on 2 November 2021).

26. Ferrante, T.; Villani, T. Il Ruolo delle Municipalità nei Progetti di Ricerca, Sviluppo e Innovazione: Transizione Verso Aree Urbane Sostenibili, ENEA, Ricerca di Sistema Elettrico, Report RdS/PTR (2020)/040. 2020. Available online: https:/ / www.enea.it/it/Ricerca_sviluppo/lenergia/ricerca-di-sistema-elettrico/accordo-di-programma-MiSE-ENEA-20 19-2021/tecnologie/tecnologie-per-la-penetrazione-efficiente-del-vettore-elettrico-negli-usi-finali/local-energy-district (accessed on 2 November 2021).

27. Bossi, S.; Gollner, C.; Theierling, S. Towards 100 Positive Energy Districts in Europe: Preliminary Data Analysis of 61 European Cases. Energies 2020, 13, 6083. [CrossRef]

28. Koskela, L.; Huovila, P.; Leinonen, J. Design management in building construction: From theory to practice. J. Constr. Res. 2020, 3 , 1-16. [CrossRef] 